\title{
NEW RECORD OF FABACEAE FOSSIL WOODS FROM THE SOLIMÕES FORMATION (MIOCENE), ACRE BASIN, AMAZON, BRAZIL
}

\author{
ADRIANA KLOSTER \\ Centro de Ecología Aplicada del Litoral, Área de Paleontología, CECOAL-CONICET, Ruta 5, km 2,5, CP. 3400, \\ Corrientes, Argentina. klosterdri@gmail.com
}

SILVIA GNAEDINGER

Centro de Ecología Aplicada del Litoral, Área de Paleontología, CECOAL-CONICET, Ruta 5, km 2,5, CP. 3400. FACENA UNNE, Casilla correo 128, CP. 3400, Corrientes, Argentina.scgnaed@hotmail.com

\author{
KAREN ADAMI-RODRIGUES \& CAMILE URBAN \\ Núcleo de Estudos em Paleontologia e Estratigrafia (NEPALE), Centro das Engenharias, UFPel, Praça Domingos \\ Rodrigues, 2, 96010-440, Pelotas, RS. Brazil.karen.adami@gmail.com,camile.urban@ufpel.edu.br
}

\begin{abstract}
Detailed descriptions are provided for specimens of a new genus and species of Mimosoideae and Swartzioxylon naraense Delteil-Desneux emended (Papilionoideae) from the Solimões Formation, Miocene, Acre Basin, Brazil. Anatomical characteristics of the woods show a resemblance with the extant genera Zygia P. Browne and Swartzia Schreb, respectively. These genera currently have a wide distribution in Brazil and throughout the Amazon region; their presence in the outcrops of the Solimões Formation supports the idea that these genera might have been important components and indicates their importance in the fossil record, both to establish its distribution and evolution from the past to present of Amazon flora.
\end{abstract}

Key words: wood anatomy, Mimosoideae, Papilionoideae, Neogene.

RESUMO - Descrições detalhadas são fornecidas para os espécimes de um novo gênero e espécie de Mimosoideae e Swartzioxylon naraense Delteil-Desneux emend. (Papilionoideae) da Formação Solimões, Mioceno, bacia do Acre, Brasil. Características anatômicas das madeiras mostram uma semelhança com os gêneros viventes Zygia P. Browne e Swartzia Schreb, respectivamente. Esses gêneros têm atualmente uma ampla distribuição no Brasil e em toda a região amazônica, sua presença nos afloramentos da Formação Solimões suporta a ideia de que poderiam ter sido importantes componentes e indica a sua importância no registro fóssil, tanto para estabelecer sua distribuição e evolução do passado ao presente da flora amazônica.

Palavras-chave: anatomia da madeira, Mimosoideae, Papilionoideae, Neógeno.

\section{INTRODUCTION}

Knowledge of Neogene floras is considered relevant to an understanding of the factors that modulated the origins of the extant floras, their patterns of evolution, and the distribution of communities as centers of biological diversity. Paleontological and geological studies performed on outcrops in the Amazonian rivers are very important for understanding and modeling Neogene environmental changes that occurred in the southwestern Amazon. In the Brazilian state of Acre, sedimentary rock from the Solimões Formation emerges alongside the Acre, Iaco, Envira, Purus, Tarauacá, and Juruá rivers (Adami-Rodrigues et al., 2013).

Fossil wood records of the Solimões Formation are scarce. Mussa (1959) provided the first descriptions of fossil woods from the Juruá River, with Fabaceae family (Zollernioxylon sommeri, Z. santosii, Z. tinocoi), Lecythidaceae family (Lecythioxylon milanezii), and Sapindaceae family (Sapindoxylon lamegoi) being identified. Pons \& De
Franceschi (2007) described and assigned fossil woods with affinities to the Anacardiaceae, Clusiaceae, Combretaceae, Humiriaceae, Lecythidaceae, Leguminosae, and Meliaceae families, but without anatomical description from the Pebas Formation, which emerges in western Peruvian Amazon in the Iquitos region. This was later designated as the Solimões Formation in Acre Basin by Hoorn \& Wesselingh (2010). Machado et al. (2012) have described new records of fossil woods showing affinities with Fabaceae (Zollernioxylon sp.) and the families Lytraceae and Myrtaceae from the Solimões Formation in the Acre Basin, and Kloster et al. (2013) have recorded a new sample of Fabaceae (Zollernioxylon tinocoi) from the same formation along the Juruá River.

Palynological data from the Amazon region suggest diverse and well-structured forest communities with pollen types belonging to taxa from all forest strata, including grasses, herbs, and understory and canopy taxa, as well as diverse types of climbing ferns and epiphytes (Jaramillo et al., 2010). Approximately 30 plant families 
have been identified for the Miocene, with a predominance of Arecaceae, Poaceae, Malvaceae, Euphorbiaceae, Malphigiaceae, Humiricaceae, and Melastomataceae (Hoorn, 1993, 1994; Latrubesse et al., 2010).

This paper adds new information to records by providing the first descriptions of Miocene fossil woods of Fabaceae family with affinity to the subfamilies Mimosoideae and Papilionoideae from the Solimões Formation.

\section{GEOLOGICAL SETTING}

The fossil woods analyzed were recovered in the Acre Basin, at the Juruá River, from a locality called Estirão do Mississippi (Figure 1). The Acre Basin extends over an area of $150,000 \mathrm{~km}^{2}$ between parallels $6^{\circ} \mathrm{S}$ and $9^{\circ} \mathrm{S}$ and meridians $72^{\circ} 30^{\prime} \mathrm{W}$ and $74^{\circ} \mathrm{W}$ (Cunha, 2007). It is geologically bounded to the east by the Iquitos Arch, to the north and northwest by the Marañon Basin, and to the south and southwest by the Ucayali Basin (Wanderley-Filho et al., 2010).

During the deposition the Acre Basin was affected by the late Hercynian and Andean orogenies (Cunha, 2007). This latter orogeny caused the uplift of the Andean Cordillera and deposition of the Solimões Formation as a typical foreland system (Wanderley-Filho et al., 2010). This redirected the fluvial system (e.g. the Solimões and Amazon rivers) into the Atlantic Ocean (Hoorn et al., 1995).

The lithotype sequence of the Solimões Formation consists of predominantly pelitic rock types, formed in a reducing environment and represented by greenish mudstones that range from light to dark and silty to sandy, and which are micaceous, locally calciferous and sometimes carbonaceous, or reddish with iron oxides, and highly fossiliferous (Maia et al., 1977). There are also minor interbedded siltstones that have carbonate concretions either dispersed or in thin sheets, often microcrystalline (calcretes), as well as levels of lignite with pyrite that become thinner from the base to the top and transition to carbonaceous mudstone. These siltstones are light greenish gray to dark gray, sometimes clay, and the sandstones have an average particle size of medium to fine. Organic remains are common in this sequence. Also according to the cited author this formation presents some oxidized facies, with reddish, purplish, yellowish and whitish mudstones, siltstones, and sandstones, and with lignite and fossil contents in lesser amounts.

The outcrops that are the focus of the present study are located along riverbanks and represent exposure of sediments from the upper parts of the Solimões Formation. Data from fossil vertebrate assemblages and palynology of Late Miocene age for these deposits (Latrubesse et al., 2010). The same authors reported an abundant and diverse vertebrate fauna from the intervals from the top of the interfluve formation, dated to the Huayquerian and Montehermosian South American land mammal ages (Miocene-Pliocene).

In their review of the paleobiogeography of the Amazonian river system, Latrubesse et al. (2010) recorded that Miocene sedimentary rocks are associated with fossil of vertebrates, mollusk, and pollen. This support a scenario of continental deposition, with the sedimentary environment probably formed by the combination of fluvial channels forming a large river system with floodplains, swamps, forests, and gallery forests, developed under a tropical to subtropical climate with a dry season. Palynological studies indicate the presence of more than 30 families of angiosperms, most of them still present in the modern landscape (e.g. Euphorbiaceae, Malvaceae, Rubiaceae and Amaranthaceae), while data from fossil vertebrate fauna suggest the presence of areas of open fields and various types of forests.

These lithological characteristics suggest a fluvial system, with interbedded floodplain deposits represented by planeparallel siltstones and debris flow deposits represented by massive clast-supporting conglomerates (Simpson \& PaulaCouto, 1981). The fossilized fragments of woods and turtle shells indicate that the depositional environment had moments of high energy, enabling the deposition of fossils and gravels. The banded iron carbonate concretions represent a postdepositional diagenetic process of palaeosol development in an arid climate. The character of the flattened and compressed woods indicates that the sedimentary basin received heavy sediment inputs, where a large volume of sediment was deposited in a short period of time.

\section{MATERIAL AND METHODS}

The fossil woods were collected from outcrops along the Juruá River in the State of Acre, more specifically in the locality known as Estirão do Mississippi, which gives its name to the stratigraphic sections adapted from Simpson \& Paula-Couto (1981) (Figure 2). Fragments of silicified woods show a good cellular preservation. Petrographic thin sections with 30-40 $\mu \mathrm{m}$ thick were prepared from the wood fragments, orientated along three sections: transversal section (TS), tangential longitudinal section (TLS), and radial longitudinal section (RLS). These thin sections were studied in detail using a Leica DM500 microscope with an attached EC2 (LM) camera, and some fragments were also observed using a Leitz M50 stereoscopic microscope Leitz and a scanning electron microscope (SEM) observations using a Jeol5800 LV at the Universidad Nacional del Nordeste, Corrientes, Argentina.

For the various anatomical elements studied, at least 20 individual measurements were taken, with values recorded as means (minimum-maximum) following Chattaway (1932). The diagnostic anatomical characteristics for the Leguminosae were taken from IAWA Committee List of Microscopic Features for Hardwood Identification (1989), the Inside Wood Database (2004 and after - http://insidewood.lib.ncsu.edu/search), Kribs (1935), Metcalfe \& Chalk (1950), Détienne \& Jacquet (1983), Wheeler \& Baas (1992), Carlquist (2001), Miller \& Détienne (2001) and Evans et al. (2006). Gregory et al. (2009) list was also used for essential bibliographic information. The systematics follows the APG III (2009) classification.

The specimens studied have been deposited under the heading LLP-CZS in the Laboratory of Paleontology and Paleobotany of Universidade Federal do Acre, Campus Cruzeiro do Sul, Brazil. 

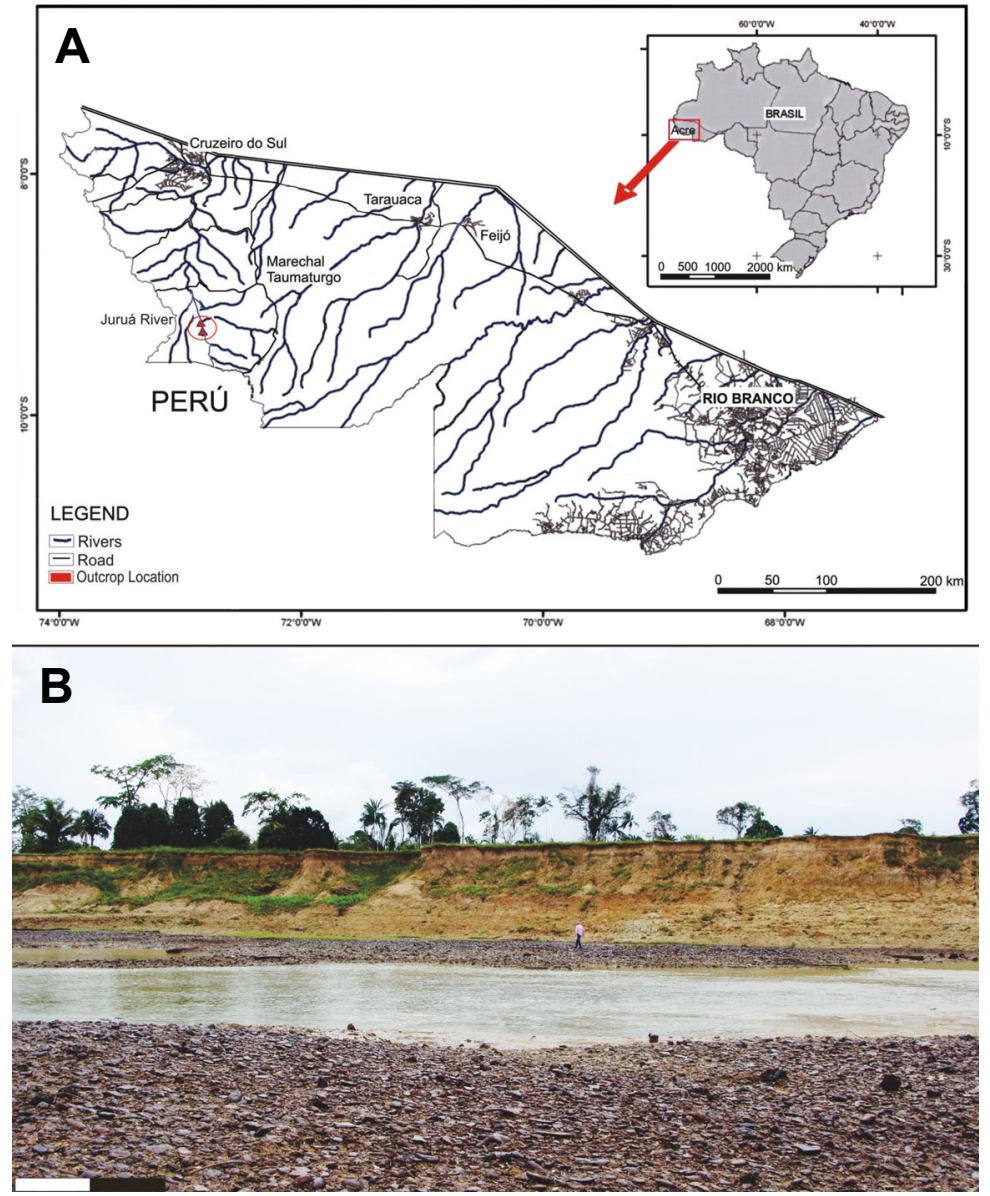

Figure 1. A, Map showing the geographical location of the study area, along the Juruá River, in the Acre state, northwestern Amazon, Brazil. B, Photo of Estirão do Mississippi locality at Juruá River, Acre Basin. Map modified from Adami-Rodrigues et al. (2013), photo of Mississippi locality by A.C. Kloster. Scale bar $=1 \mathrm{~m}$.
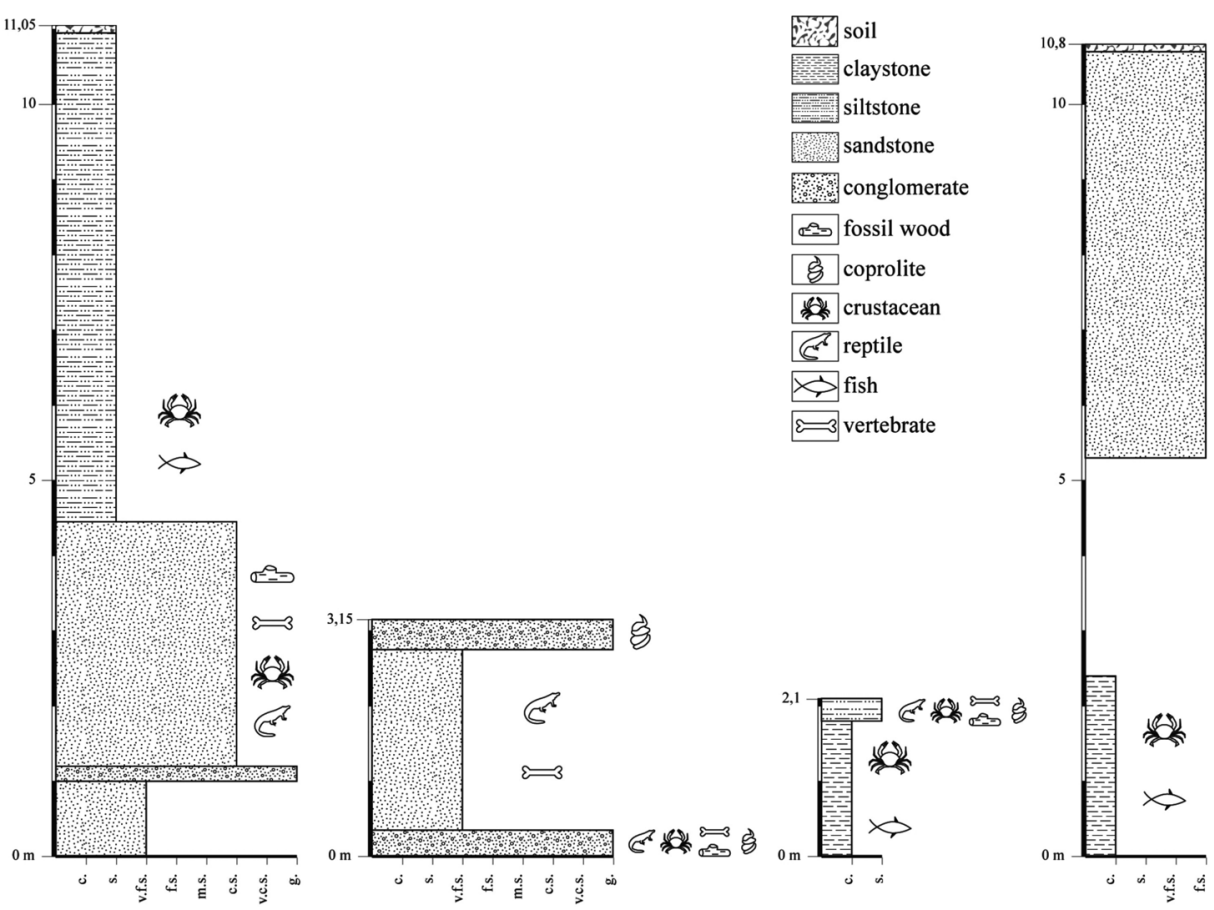

Figure 2. Stratrigraphic profile of Estirão do Mississippi locality. Fossil woods were collected in the sandstone levels. Profile adapted from Simpson \& Paula-Couto (1981). 
The Fabaceae fossil. Herendeen et al. (1992) attributed the abundance of legumes in the Cenozoic fossil record, at least in part, to their ability to inhabit any environment, including disturbed areas such as streambeds and lake margins. The extensive diversification of the family into three subfamilies occurred during the Eocene (Herendeen et al., 1992) and was accompanied by the "distribution" of dry climates in the tropics, creating groves in which each type of legume was common (Axelrod, 1992). The subsequent development of topographic complexity accompanied by formation of mountains and valleys was also conducive to occupation by legumes. Currently the Fabaceae is the third-largest family and they occupy almost environments. Africa and India have the most extensive fossil records for the Fabaceae, followed by the Americas and Europe (Gregory et al., 2009). According to Jacobs (2004) the oldest legume yet discovered is a mid-Eocene sample from northern Tanzania, which was even suggested to be a center of origin for the subfamily Caesalpinoideae.

\section{SYSTEMATIC PALEOBOTANY}

\author{
EUDICOTS sensu APG III \\ Core EUDICOTS sensu APG III \\ FABIDS sensu APG III \\ FABALES Bromhead \\ Family FABACEAE Lindley. nom. cons. Leguminosae \\ Jussieu, nom. cons. et nom. alt. \\ Subfamily MIMOSOIDEAE De Candolle, 1825
}

\section{Zygiaxylon gen. nov. Kloster \& Gnaedinger}

Type species. Zygiaxylon amazonicum sp. nov., by monotypy.

Etymology. Generic epithet refers to the extant genus Zygia Browne.

Diagnosis. Growth rings indistinct or absent. Diffuse porous wood without a clear pattern of distribution. Vessels commonly solitary or in radial multiples, some clusters, gum deposits presents. Simple perforation plates. Intervessel pits small, alternate, and vestured. Vessel-ray pits with distinct borders, similar to intervessel pits in size and shape throughout the ray cell. Axial parenchyma vasicentric, aliform to confluent, forming irregular wide bands, occasionally apotracheal parenchyma diffuse present. Simple fibers, non-septate. Rays are homogeneous, mostly 1 -seriate or occasionally, 1 -seriate partially 2 -seriate, homocellular, formed by procumbent cells, not storied. Crystals in chambers present in the axial parenchyma.

\section{Zygiaxylon amazonicum sp. nov. Kloster \& Gnaedinger} (Figures 3-4A-B)

Holotype. LPP-CZS 0061.

Repository. Laboratory of Paleontology and Paleobotany of Universidade Federal do Acre, Campus Cruzeiro do Sul, Brazil.
Type locality. Estirão do Mississipi, Juruá River, State of Acre, Brazil.

Stratigraphic horizon. Solimões Formation, Acre Basin. Etymology. Specific epithet refers to the Amazon region, where this fossil was recovered.

Diagnosis. The same to the genus by monotypy.

Description. This description is based on a specimen of silicified wood measuring $15 \mathrm{~cm}$ long and $10 \mathrm{~cm}$ in diameter. Pith, primary xylem, outer cortex, and secondary phloem are not preserved. The growth ring boundaries are indistinct or absent. The porosity is diffuse, without a clear pattern of distribution (Figure 3A). The vessels are more or less circular, solitary $(62.5 \%)$ or in multiples of 2,3 , or $4-5(19.64 \%, 12.5 \%$, $5.35 \%$, respectively), some clusters (Figure $3 \mathrm{~A}$ ). The mean vessel element tangential diameter is $195.2 \mu \mathrm{m}(72-268 \mu \mathrm{m})$ and mean radial diameter is $142.9 \mu \mathrm{m}(89-251 \mu \mathrm{m})$, mean vessels per $\mathrm{mm}^{2} 7\left(5-8\right.$ per $\left.\mathrm{mm}^{2}\right)$ (Figures 3A-B), mean vessel element length $354 \mu \mathrm{m}(153-512 \mu \mathrm{m})$ (Figure $3 \mathrm{C})$, gum/resin deposits present between vessels elements (Figures 3C,4A). Ground tissue fibers are circular to polygonal in outline, nonseptate, with a mean diameter of 3.75 $\mu \mathrm{m}(3-7 \mu \mathrm{m})$ (Figure 3 B). Simple perforation plates with oblique end walls and intervessel pits alternate, small to medium and vestured, mean $5 \mu \mathrm{m}(3-7 \mu \mathrm{m})$ in diameter (Figures 3D,4B). Vessel-ray pits with distinct borders, similar to intervessel pits in size and shape throughout the ray cell (Figure 3C). Axial paratracheal parenchyma vasicentric, aliform to confluent, forming irregular wide bands more than three cells wide, occasionally apotracheal parenchyma diffuse present, some crystals in chambers present (Figures 3A-B). Rays are homogeneous, mostly 1 -seriate or occasionally 1 -seriate partially 2 -seriate (Figures 3E-F), mean height $291 \mu \mathrm{m}(209-384 \mu \mathrm{m})$ and mean width $23.5 \mu \mathrm{m}(19-28 \mu \mathrm{m}), 15$ (3-24) cells high, mean 15 rays per mm, composed by procumbent cells, not storied. Crystals in chambers present in the axial parenchyma (Figure 3G).

Remarks. The presence of characters such as solitary and multiple vessels, simple perforation plates, alternate and vestured intervessel pits, vessel-ray pits similar to intervessel pits in size and shape, confluent aliform or vasicentric axial parenchyma forming bands, and homogeneous rays suggest affinity with the Fabaceae family (Metcalfe \& Chalk, 1950; Cozzo, 1951; Wheeler \& Baas, 1992). The fossil woods described here have been compared with mostly Miocene fossil wood records. The fossil genera referred to Mimosoideae are: Acacioxylon Schenk, 1883, Adenantheroxylon Prakash \& Tripathi, 1968, Albizinium Prakash, 1975, Albizzioxylon Nikitin, 1935, Dichrostachyoxylon Müller-Stöll \& Mädel, 1967, Eucacioxylon Müller-Stöll \& Mädel, 1967, Ingoxylon Müller-Stöll \& Mädel, 1967, Menendoxylon Lutz, 1979, Metacacioxylon Gros, 1981, Mimosoxylon Müller-Stöll \&Mädel, 1967, Mimosaceoxylon Lakhanpal \& Prakash, 1970, Paraalbizioxylon Gros, 1992 diagnosis emended by Martínez (2014), Paracacioxylon Müller-Stöll \& Mädel, 1967, Piptadenioxylon Suguio \& Mussa, 1978, Tetrapleuroxylon Müller-Stöll \& Mädel, 1967, Anadenantheroxylon Brea et al., 2001, diagnosis emended by Franco (2011) and Microlobiusxylon Franco \& Brea, 2010 (Table 1). The fossil 

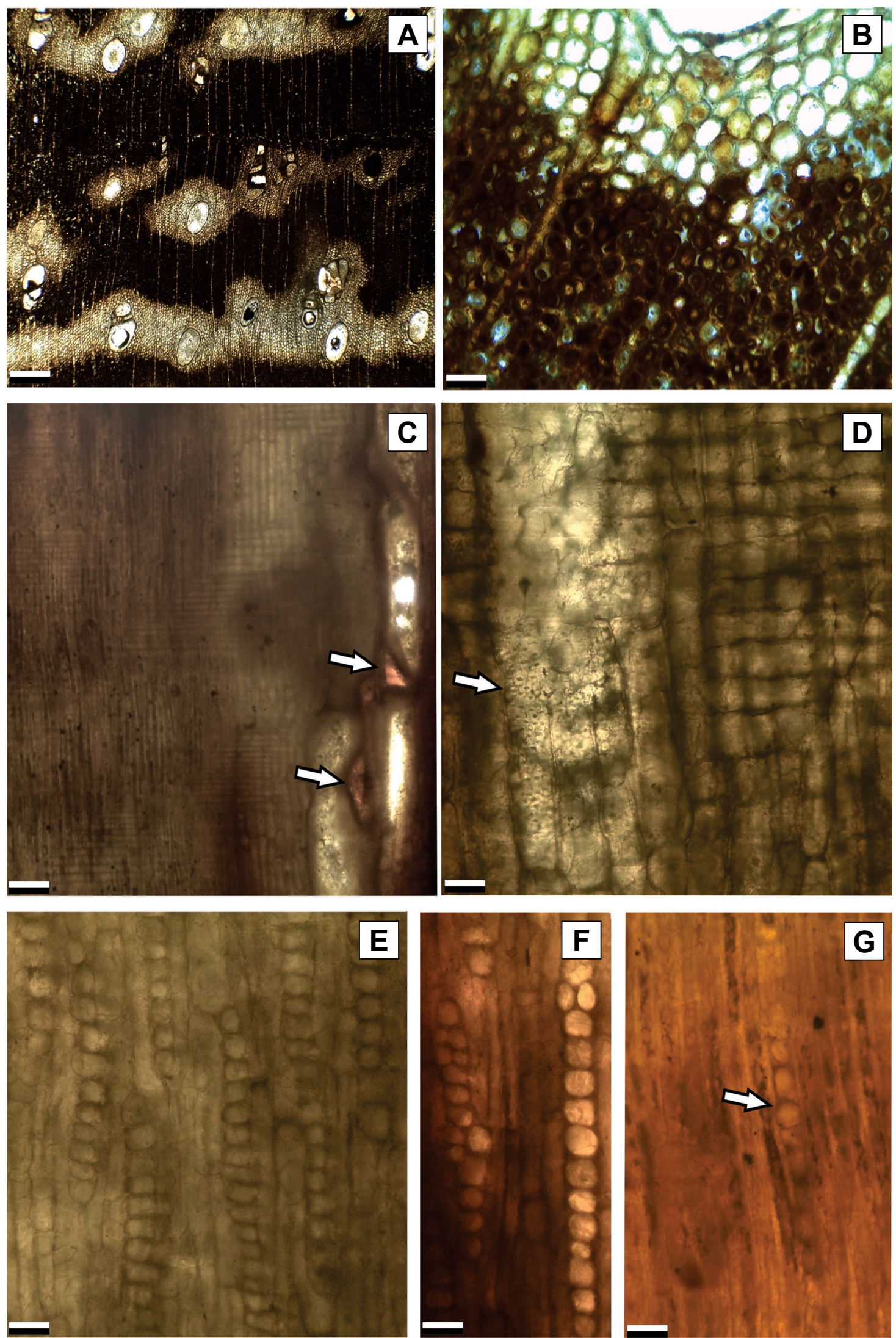

Figure 3. Zygiaxylon amazonicum gen. et sp. nov. (LPP-CZS 0061 holotype). A, TS, general view. Diffuse porous, vessels, parenchyma and fibers distribution; B, TS, detail of parenchyma and fibers; C, RLS, vessel elements, gum deposits (arrow) and distribution of rays and parenchyma; D, TSL, vessel ray pits (arrow), similar to intervessel pits; E, TLS, rays homogeneous 1-seriate and 1-seriate partially 2-seriate composed by procumbent cells, not storied; $\mathbf{F}$, TLS, detail of homogeneous rays, 1 -seriate partially 2 -seriate; $\mathbf{G}$, RLS, chambered crystal (arrow) present in axial parenchyma cells. Abbreviations: see Material and Methods. Scale bars: $A, C-D, G=50 \mu \mathrm{m} ; B=10 \mu \mathrm{m} ; E-F=30 \mu \mathrm{m}$. 
sample was compared to the genus mentioned on (Table 1) and present more similarity in the group of diagnostically characters with: Anadenantheroxylon, Microlobiusxylon and Piptadenioxylon but differs by having different density of vessels by $\mathrm{mm}^{2}$, and because the rays are low in Microlobiusxylon and 2-3 seriate in Piptadenioxylon, and differs of Anadenantheroxylon by having axial parenchyma completely vasicentric, aliform (rhomboid) and confluent, neither rays 1-3 seriates (Table 1 ).
In the subfamily Mimosoideae, the Ingeae tribe is the largest, and it includes about ten genera and 300 extant species. Following Evans et al. (2006) the Inga alliance can be divided into genera with septate fibers and those with nonseptate fibers, although most of the genera have uniseriate rays that are nearly always homocellular. Generally, the elements are not storied, but sometimes the rays may appear to be partially storied. Calcium oxalate crystals are common and are found predominantly in chambered fibers, and to a

Table 1. Comparisons between fossil genera of Mimosoideae (adapted from Gros, 1992).

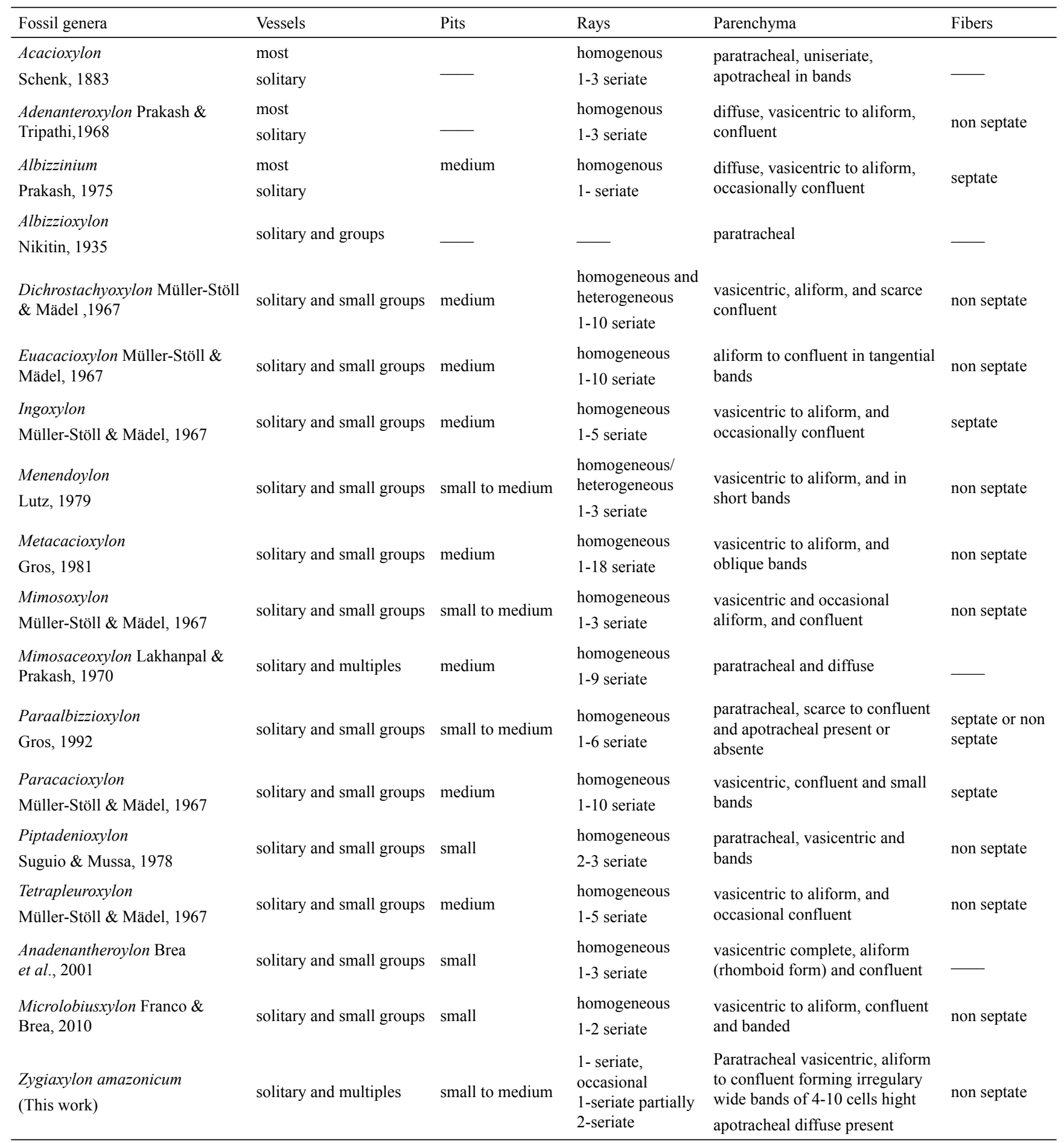


lesser degree in chambered axial parenchyma cells. Gum deposits are very common and found in vessels, ray cells, axial parenchyma, and fibers. León (2008) also establishes the difference between genres of 31 species of Mimosoideae from Venezuela, taking characters as the presence or absence of septate fibers, parenchyma type and rays.

This specimen was compared with the extant species that now inhabit the Amazon region, whether endemic or not, and which present similar anatomical features: Abarema jupunba Willd, Enterolobium maximum Ducke, Inga alba Willd, and Marmaroxylon racemosum Killip, Zygya longifolia Willd and Zygia cauliflora Killip. The specimen is comparable to all of these genera in terms of its wood anatomy as density of vessels, tangential diameter of vessels, size and shape of intervessel pits, axial parenchyma type and distribution, fibers, rays, crystals and gum deposits. However, it seems to show closest affinity with Zygia based upon the types and distributions of its axial parenchyma and rays major uniseriate and occasionally uniseriate partially biseriate (see Table 2); the other genera feature 1-3 seriate rays series. The specimen presents more similarity in density of vessels by $\mathrm{mm}^{2}$ and tangential diameter with $Z$. cauliflora, Z. longifolia and Marmaroxylon racemosum. Axial parenchyma and rays more similar to Z. cauliflora and Z. longifolia. Fibers more similar with Abarema jupunba, Z. cauliflora and Z. longifolia. Presence of gum deposits are present in Abarema jupunba, I. alba, Z. cauliflora and Z. longifolia (Table 2).

Therefore, the sample described here presents characteristics that are especially similar to those of the extant neotropical and the absence of a fossil genus that shares all of the characteristics presented by the fossil in question, justifies the creation of the new genus Zygiaxylon, with the name reflecting its similarities with the extant genus Zygia.

Species from Ingeae tribe currently can be found in the forests of Africa, Asia, and Australia, as well as in Central America and throughout South America. In Brazil, their occurrence is recorded in all seven biomes, with the greatest center of diversity found in the Amazon region (Ducke, 1943). In the Brazilian Amazon the tribe is represented by 206 species in 14 genera. Studies on this group have determined that the species are limited to the rainforest areas, many of which are typically secondary forests on poorly drained or periodically flooded land areas (Pennington, 1997). As suggested by Herendeen et al. (1992), the Fabaceae show the ability to adapt to any environment. Early studies of extant legumes for the Brazilian Amazon were performed by Ducke (1925, 1930, 1943), with a large number of species having first been described in these sources.

Table 2. Comparisons between extant species of Mimosoideae.

\begin{tabular}{|c|c|c|c|c|c|c|c|c|}
\hline Extant specie & Reference & Vessels & $\begin{array}{c}\text { Intervascular } \\
\text { pits }\end{array}$ & Axial parenchyma & Rays & Fibers & Crystal & $\begin{array}{c}\text { Gum/ resin } \\
\text { deposits }\end{array}$ \\
\hline $\begin{array}{l}\text { Abarema } \\
\text { jupunba } \\
\text { Willd }\end{array}$ & $\begin{array}{l}\text { León, } \\
2008\end{array}$ & $\begin{array}{c}3-4 \mathrm{~mm}^{2} \\
135-255 \mu \mathrm{m}\end{array}$ & $\begin{array}{l}\text { alternate } \\
\text { minute to } \\
\text { small } \\
\text { vestured }\end{array}$ & $\begin{array}{l}\text { Paratracheal vasicentric, } \\
\text { aliform to confluent in } \\
\text { short wing. Occasionally } \\
\text { apotracheal diffuse present } \\
\text { on small islands }\end{array}$ & $\begin{array}{c}\text { homogeneous } 1-3 \\
\text { seriate } \\
3-7 \mathrm{~mm} \\
170-460 \mu \mathrm{m} \text { height }\end{array}$ & $\begin{array}{c}\text { non } \\
\text { septated }\end{array}$ & & present \\
\hline $\begin{array}{l}\text { Enterolobium } \\
\text { maximum } \\
\text { Ducke }\end{array}$ & $\begin{array}{c}\text { Détienne } \\
\text { \& Jacquet, } \\
1983\end{array}$ & $\begin{array}{c}5 \mathrm{~mm}^{2} \\
170-240 \mu \mathrm{m}\end{array}$ & $\begin{array}{l}\text { alternate } \\
\text { medium } \\
\text { vestured }\end{array}$ & $\begin{array}{l}\text { Paratracheal vasicentric, } \\
\text { aliform to confluent in } \\
\text { lozenge type } 2-6 \text { cells hight }\end{array}$ & $\begin{array}{c}\text { homogeneous } 1-3 \\
\text { seriate } \\
5-7 \mathrm{~mm}\end{array}$ & $\begin{array}{c}\text { some } \\
\text { septated }\end{array}$ & present & - \\
\hline $\begin{array}{l}\text { Inga alba } \\
\text { Willd }\end{array}$ & $\begin{array}{l}\text { Miller \& } \\
\text { Détienne, } \\
2001\end{array}$ & $\begin{array}{c}1-3 \mathrm{~mm}^{2} \\
200-250 \mu \mathrm{m}\end{array}$ & $\begin{array}{l}\text { alternate } \\
\text { medium } \\
\text { vestured }\end{array}$ & $\begin{array}{l}\text { Paratracheal vasicentric, } \\
\text { aliform to confluent in } \\
\text { lozenge type } 2-6 \text { cells hight }\end{array}$ & $\begin{array}{c}\text { homogeneous } 1-3 \\
\text { seriate } \\
7-10 \mathrm{~mm}\end{array}$ & septated & present & present \\
\hline $\begin{array}{l}\text { Marmaroxylon } \\
\text { racemosum } \\
\text { Killip }\end{array}$ & $\begin{array}{l}\text { Détienne } \\
\text { \& Jacquet, } \\
1983\end{array}$ & $\begin{array}{c}5 \mathrm{~mm}^{2} \\
160-200 \mu \mathrm{m}\end{array}$ & $\begin{array}{l}\text { alternate } \\
\text { small } \\
\text { vestured }\end{array}$ & $\begin{array}{l}\text { Paratracheal vasicentric, } \\
\text { aliform to confluent in } \\
\text { lozenge type } 2-6 \text { cells hight }\end{array}$ & $\begin{array}{c}\text { homogeneous } 1-3 \\
\text { seriate } \\
5-7 \mathrm{~mm}\end{array}$ & $\begin{array}{c}\text { some } \\
\text { septated }\end{array}$ & present & $\longrightarrow$ \\
\hline $\begin{array}{l}\text { Zygia cauliflora } \\
\text { Killip }\end{array}$ & $\begin{array}{l}\text { Détienne } \\
\text { \& Jacquet, } \\
1983\end{array}$ & $\begin{array}{c}2-6 \mathrm{~mm}^{2} \\
110-170 \mu \mathrm{m}\end{array}$ & $\begin{array}{l}\text { alternate } \\
\text { small } \\
\text { vestured }\end{array}$ & $\begin{array}{l}\text { Paratracheal vasicentric, } \\
\text { aliform to confluent in } \\
\text { lozenge type } 2-4 \text { cells hight }\end{array}$ & $\begin{array}{l}\text { homogeneous } 10 \\
\text { mm uniseriate, } \\
\text { occasional } \\
\text { uniseriate partially } \\
\text { biseriate }\end{array}$ & $\begin{array}{c}\text { non } \\
\text { septated }\end{array}$ & present & present \\
\hline $\begin{array}{l}\text { Zygia longifolia } \\
\text { (Humb. \& } \\
\text { Bonpl. ex } \\
\text { Willd.) }\end{array}$ & $\begin{array}{l}\text { León, } \\
2008\end{array}$ & $\begin{array}{c}10-12 \mathrm{~m}^{2} \\
70-140 \mu \mathrm{m}\end{array}$ & $\begin{array}{l}\text { alternate } \\
\text { small to } \\
\text { medium } \\
\text { vestured }\end{array}$ & $\begin{array}{l}\text { Paratracheal vasicentric, } \\
\text { aliform to confluent in } \\
\text { wide bands; apotracheal } \\
\text { diffuse present }\end{array}$ & $\begin{array}{c}\text { homogeneous } \\
\text { uniseriate, } \\
\text { occasional } \\
\text { uniseriate partially } \\
\text { biseriate } \\
6-12 \mathrm{~mm} \\
90-310 \mu \mathrm{m} \text { height }\end{array}$ & $\begin{array}{c}\text { non } \\
\text { septated }\end{array}$ & present & present \\
\hline $\begin{array}{l}\text { Zygiaxylon } \\
\text { amazonicum } \\
\text { (This work) }\end{array}$ & this work & $\begin{array}{c}5-8 \mathrm{~mm}^{2} \\
(89-251) \\
195 \mu \mathrm{m}\end{array}$ & $\begin{array}{l}\text { alternate } \\
\text { small to } \\
\text { medium } \\
\text { vestured }\end{array}$ & $\begin{array}{l}\text { Paratracheal vasicentric, } \\
\text { aliform to confluent } \\
\text { forming irregulary wide } \\
\text { bands of } 4-10 \text { cells hight; } \\
\text { apotracheal diffuse present }\end{array}$ & $\begin{array}{c}\text { homogeneous } \\
\text { uniseriate, } \\
\text { occasional } \\
\text { uniseriate partially } \\
\text { biseriate } \\
10 \mathrm{~mm} \\
209-384 \mu \mathrm{m} \text { height }\end{array}$ & $\begin{array}{c}\text { non } \\
\text { septated }\end{array}$ & present & present \\
\hline
\end{tabular}


Subfamily PAPILIONOIDEAE De Candole, 1825

Swartzioxylon Delteil-Desneux, 1980 emend. Kloster \& Gnaedinger

Type species. Swartzioxylon naraense Delteil-Desneux, 1980.

Emended diagnosis. Growth rings indistinct to absent. Diffuse porous. Vessels commonly solitary or in radial multiples; small vessels with scarce clustering. Simple perforation plates oblique or horizontal. Intervessel pits alternate, small and vestured; vessel-ray pits with distinct borders, similar to intervessel in size and shape throughout the ray cell. Simple fibers very thin-walled. Axial parenchyma vasicentric to aliform and in scarce bands. Rays homogeneous, numerous and storied. Chambered crystals present in the axial parenchyma.

Remarks. Generic diagnosis was emended to include the small size and vesturing of intervessel pits, description of vessel-ray pits, scarce clustering, classification of the ray cells, and arrangement of axial parenchyma.
Swartzioxylon naraense Delteil-Desneux, 1980 emend. Kloster \& Gnaedinger

(Figures 4C-D,5)

Specific diagnosis. Growth rings indistinct or absent; diffuse porous and low density of vessels; vessels commonly solitary or in radial multiples; very small vessels; scarce clustering; simple perforation plates oblique or horizontal. Intervascular pits alternate, small and vestured. Vessel-ray pits with distinct borders, similar to intervessel in size and shape throughout the ray cell. Simple fibers very thin-walled. Axial parenchyma vasicentric, aliform, confluent and in scarce bands. Rays homogeneous, 1-2 seriate, 9-14 per mm linear and very low, storied. Chambered crystals present on axial parenchyma.

Material studied. LPP-CZS 0069.

Repository. Laboratory of Paleontology and Paleobotany of Universidade Federal do Acre, Campus Cruzeiro do Sul, Brazil.

Stratigraphic horizon. Solimões Formation, Acre Basin. Type locality. Estirão do Mississipi, Juruá River, State of Acre, Brazil.
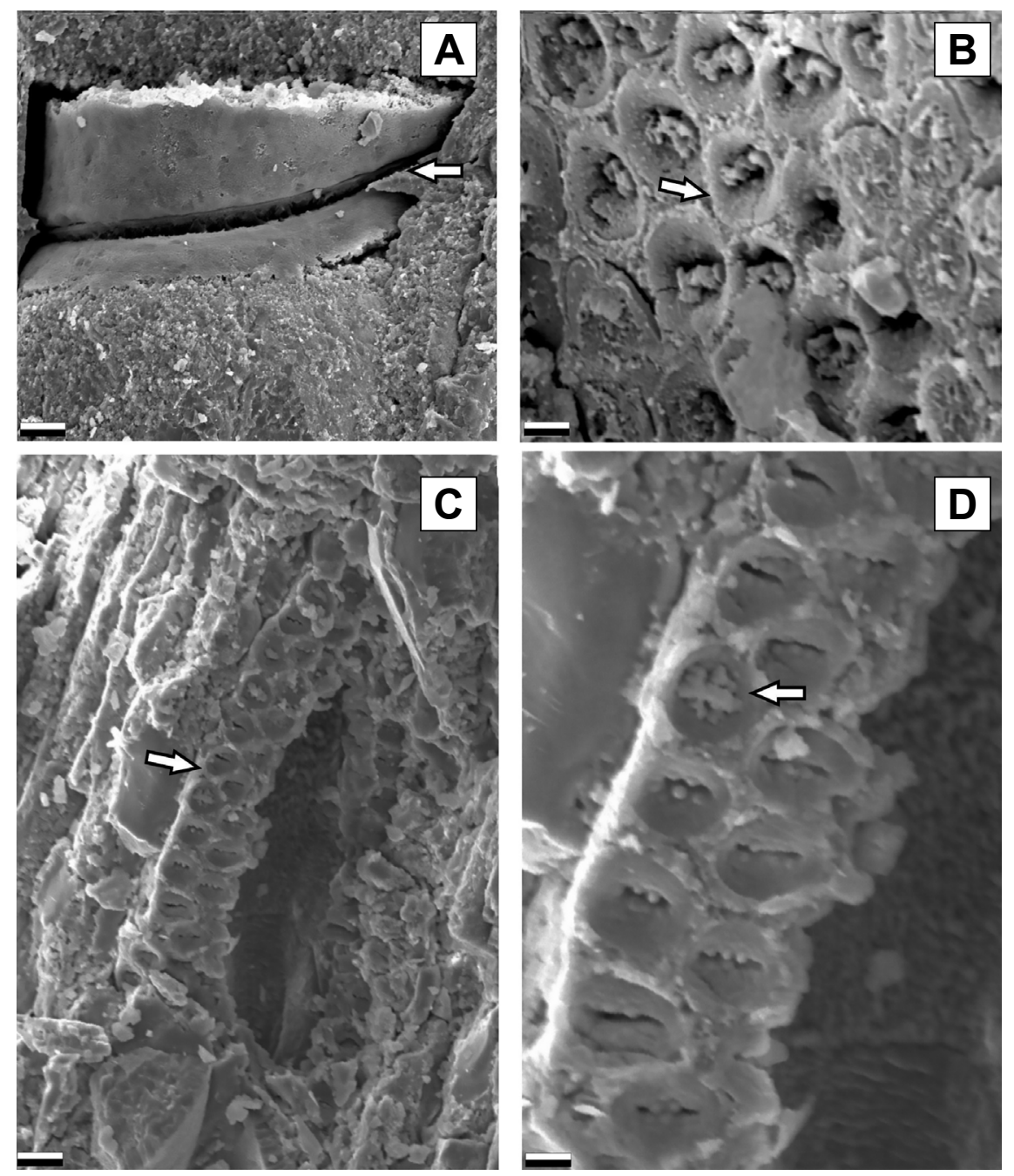

Figure 4. SEM. A-B, Zygiaxylum amazonicum gen. et sp. nov. (LPP-CZS 0061 holotype); A, TS, gum deposits between vessels (arrow); B, RLS, detail of small and vestured intervessel pits (arrow). C-D, Swartzioxylon naraense (LPP-CZS 0069 holotype), RLS, detail of small and vestured intervessel pits (arrows). Abbreviations: see Material and Methods. Scale bars: $A=30 \mu \mathrm{m} ; \mathrm{B}-\mathrm{D}=5 \mu \mathrm{m}$. 
Description. This description is based in one piece of silicified wood measuring $20 \mathrm{~cm}$ long and $15 \mathrm{~cm}$ in diameter. Pith, primary xylem, outer cortex, and secondary phloem are not preserved. Growth ring indistinct or absent. Diffuse porous with diagonal and/or radial patterning (Figure 5A). The vessels are more or less circular, solitary $(55 \%)$ or in multiples of 2,3 , or $4(30 \%, 9 \%, 6 \%$, respectively), and rarely in clusters (Figures 5A-C). Mean vessel tangential diameter of $87.4 \mu \mathrm{m}(31.5-137 \mu \mathrm{m})$, mean vessel element length 198.8 $\mu \mathrm{m}(100-269 \mu \mathrm{m})\left(\right.$ Figure 5D). Mean vessels per $\mathrm{mm}^{2} 22$ (17-27 per $\mathrm{mm}^{2}$ ) (Figure 5A), simple perforation plates with transverse or oblique end walls and intervessel pits alternate, small and vestured, mean $6 \mu \mathrm{m}(5-8 \mu \mathrm{m})$ (Figures 4C-D,5E). Vessel-ray pits with distinct borders, similar to intervessel pits in size and shape throughout the ray cell (Figure 5F). Ground tissue fibers are circular to polygonal in outline, non-septate, with a mean diameter of 5.5 $\mu \mathrm{m}(4.5-6.7 \mu \mathrm{m})$ (Figure 5C). Axial paratracheal parenchyma vasicentric, aliform to confluent (Figures 5A-C). Rays are 1-seriate and 2-seriate with mean height of $25 \mu \mathrm{m}(15-32 \mu \mathrm{m})$ and mean width of $6.8 \mu \mathrm{m}(5-10 \mu \mathrm{m}), 6(2-10)$ cells high, mean of 12 rays per $\mathrm{mm}$, homogeneous Kribs type III, composed entirely of procumbent ray cells. All elements storied (Figures 5G-H). Chambered crystals present in axial parenchyma (Figure 5I).

Remarks. The subfamily Papilionoideae is represented by characteristics including vessels solitary and in radial multiples of 2 or 3; simple perforation plates; alternate intervessel pits; and very small, vestured vessel-ray pits similar to intervessel pits. Axial parenchyma is usually abundant, confluent and banded, with chambered crystals present in most genera. Rays are mostly 1 to 3 seriate, homocellular, and composed of procumbent cells, with nonseptate fibers and rays storying (Metcalfe \& Chalk, 1950; Cozzo, 1951; Wheeler \& Baas 1992). In the present work more comparisons were made, with Dalbergioxylon antiquum Ramanujam, 1960 and Dalbergioxylon dicorynioides Müller-
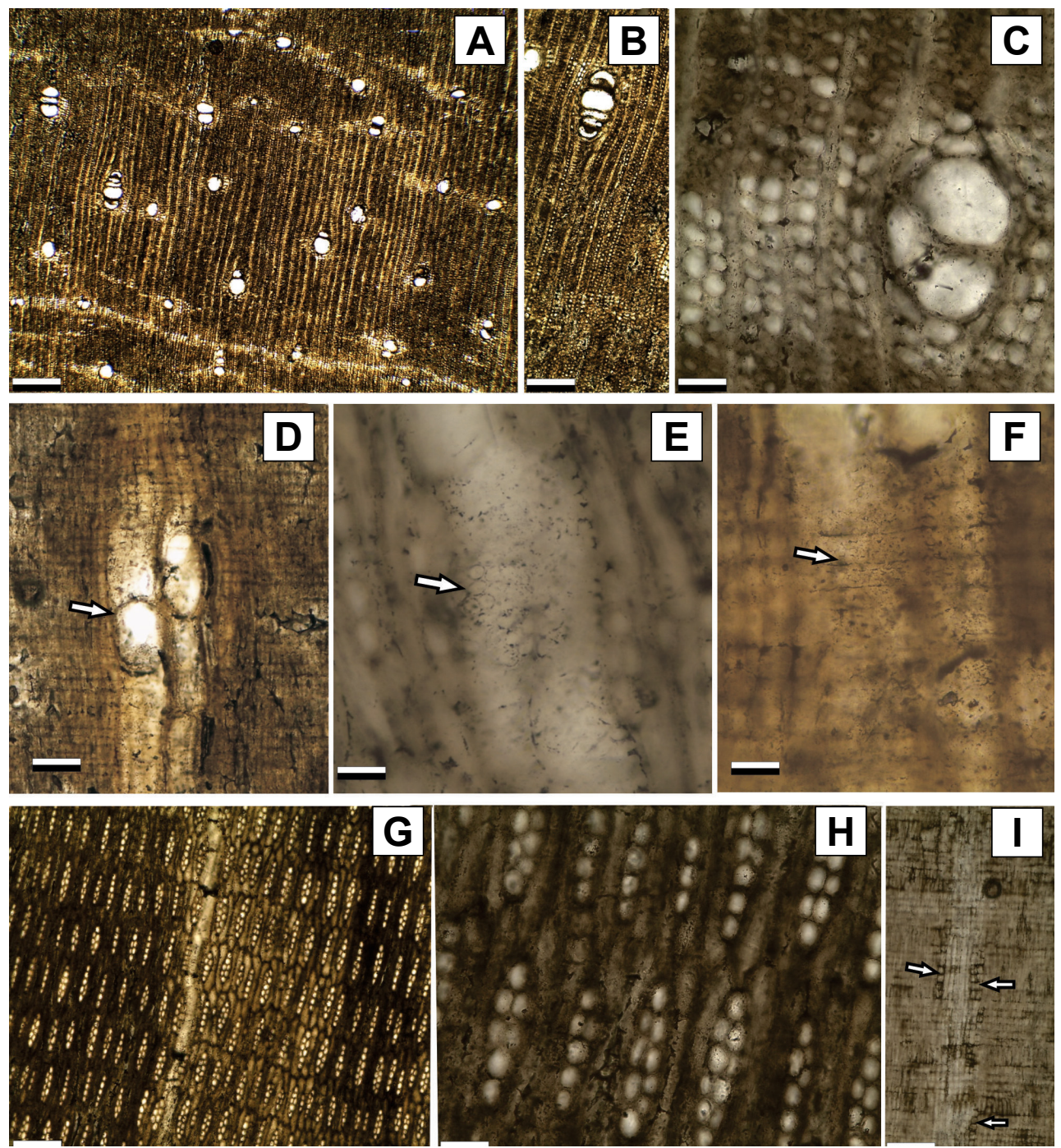

Figure 5. Swartzioxylon naraense (LPP-CZS 0069). A-B, TS, general view, diffuse porous, vessels solitaries and multiples and parenchyma distribution; C, TS, detail of a solitary vessel, axial parenchyma and fibers; D, RLS, vessel elements and simple perforation plates (arrow); E, RLS, detail of a vessel and intervessel pits small, alternate and vestured (arrow); F, RLS, vessel-ray pits, similar to intervessel pits (arrow); G-H, TLS, rays homogeneous, 1-seriate, 1-seriate partially 2-seriate and 2-seriate, parenchyma and rays storied; I, TLS, chambered crystals; present in axial parenchyma (arrows). Abbreviations: see Material and Methods. Scale bars: A-D, $50 \mu \mathrm{m} ; \mathrm{E}-\mathrm{I}=30 \mu \mathrm{m}$. 
Stoll \& Mädel, 1967 differing from Swartzioxylon naraense by having fewer vessels per $\mathrm{mm}^{2}$ and rays 1 to 3 seriate and higher. When compared with Andiroxylon cinnamomeus Martinez-Cabrera, S. naraense differs because the former has heterogeneous rays, and it differs from Pterocarpoxylon arcotense Ramanujam (1960) by having more vessels per $\mathrm{mm}^{2}$ and lower rays. Swartzioxylon naraense was also compared with the extant genera Pterocarpus Jacquet and Cynometra L. and the fossil taxa Pterocarpoxylon arambourgii Boureau, P. tibestiense Boureau, Caesalpinioxylon tchadense Koeninger, and Paratrichilioxylon Koeninger (Table 3). Because of the great similarity between the sample of Solimões Formation and $S$. naraense it was decided to include the sample in the specie previously described and an emend have been made to the description by DelteilDesneux (1980).

Currently both of these tribes are well represented in Amazonian rainforest. With approximately 68 species, the genus Swartzia Schereber is the most extensively represented member of subfamily Papilionoideae (Ribeiro et al., 1999). However, Swartzia was previously considered as belonging to subfamily Caesalpinioideae, and discussion of this group's position has continued up until the present time. Both of the tribes mentioned are very well distributed throughout the Amazon region as trees, shrubs, and lianas.

For the Neogene record in the Americas, Mussa (1959) described the morphogenus Zollernioxylon Mussa from the Solimões Formation and assigned three new fossil species.
Boureau \& Salard (1962) described a fossil wood assigned to Ficoxylon cretaceum Schenk, and Suguio \& Mussa, 1978 described two new fossil species: Piptadenioxylon chimeloi and Myrocarpoxylon sanpaulense. From the department of Sucre in Colombia, Pons (1980) described a new Pliocene morphogenus Crudioxylon. Selmeier (2004) described Crudioxylon brasilense from Cenozoic sediments collected in the Parnaiba Basin in the Brazilian State of Maranhão, although without establishing greater accuracy in terms of age. Finally, Pons \& De Franceschi (2007) briefly mention two Miocene woods from the Pebas Formation in Peru, one with affinity to Andira Jussieu or Hymenolobium Bentham and the other to the Ingeae tribe, although they do not provide anatomical descriptions.

The South American fossil wood record was recently reviewed in a paper by Pujana et al. (2011), who state that the best represented subfamily is the Mimosoideae, followed by the Papilionoideae and Caesalpinoideae. Most recently from this region a new record of Zollernioxylon sp. from the Solimões Formation was published by Machado et al. (2012), as well as a new record of Zollernioxylon tinocoi by Kloster et al. (2013) from the Solimões Formation in the Acre Basin.

\section{FINAL CONSIDERATIONS}

The specimens described here provide new evidence regarding the past distribution of the Papilionoideae and Mimosoideae subfamilies, which appears to be similar to

Table 3. Fossil wood species compared with Swartzioxylon naraense.

\begin{tabular}{|c|c|c|c|c|c|c|c|}
\hline $\begin{array}{l}\text { Species } \\
\text { Age/Country }\end{array}$ & Vessels & $\begin{array}{c}\text { Intervessel } \\
\text { Pits }\end{array}$ & Parenchyma & Fibres & Rays & Storied & Crystals \\
\hline $\begin{array}{l}\text { Dalbergioxylon antiquum Ramanujam, } \\
1960 \\
\text { Miocene/India }\end{array}$ & $\begin{array}{c}190-275 \mu \mathrm{m} \\
6-12 \mathrm{~mm}^{2}\end{array}$ & $\begin{array}{c}\text { small } \\
\text { alternate }\end{array}$ & $\begin{array}{c}\text { abundant } \\
\text { aliform - } \\
\text { confluent } \\
\text { and apotracheal }\end{array}$ & $\begin{array}{c}\text { non } \\
\text { septate }\end{array}$ & $\begin{array}{c}\text { 8-14 per mm } \\
\text { 1-3 seriates, } \\
\text { most } 3 \text {-seriate } \\
\text { heterogeneous }\end{array}$ & + & \\
\hline $\begin{array}{l}\text { Pterocarpoxylon arcotense } \\
\text { Ramanujam, } 1960 \\
\text { Miocene/ India }\end{array}$ & $\begin{array}{l}165-215 \mu \mathrm{m} \\
10-15 \mathrm{~mm}^{2}\end{array}$ & $\begin{array}{l}\text { very small } \\
\text { alternate } \\
\text { vestured }\end{array}$ & $\begin{array}{c}\text { abundant, } \\
\text { aliform- } \\
\text { confluent } \\
\text { and apotracheal }\end{array}$ & $\begin{array}{c}\text { non } \\
\text { septate }\end{array}$ & $\begin{array}{c}\text { 12-18 per mm } \\
\text { 1-2 seriate, } \\
\text { Most } 1 \text {-seriate } \\
\text { homogeneous }\end{array}$ & + & \\
\hline $\begin{array}{l}\text { Dalbergioxylon dicorynioides } \\
\text { Müller-Stöll \& Mädel, } 1967 \\
\text { Oligocene/Egypt }\end{array}$ & $\begin{array}{c}<350 \mu \mathrm{m} \\
5-20 \mathrm{~mm}^{2}\end{array}$ & $\begin{array}{l}\text { very small } \\
\text { alternate }\end{array}$ & $\begin{array}{c}\text { aliform } \\
\text { confluent } \\
\text { banded }\end{array}$ & $\begin{array}{c}\text { non } \\
\text { septate }\end{array}$ & $\begin{array}{c}\text { 4-12 mm } \\
\text { 1-3 seriate } \\
\text { homogeneous }\end{array}$ & + & ـ \\
\hline $\begin{array}{l}\text { Andiroxylon cinnamomeus } \\
\text { Martinez-Cabrera, } 2006 \\
\text { Miocene/Mexico }\end{array}$ & $\begin{array}{l}100-200 \mu \mathrm{m} \\
5-20 \mathrm{~mm}^{2}\end{array}$ & $\begin{array}{c}\text { small } \\
\text { alternate }\end{array}$ & $\begin{array}{l}\text { aliform } \\
\text { confluent } \\
\text { banded }\end{array}$ & $\begin{array}{c}\text { non } \\
\text { septate }\end{array}$ & $\begin{array}{c}\text { 4- } 12 \mathrm{~mm} \\
1-3 \text { seriate } \\
\text { Heterogeneous }\end{array}$ & + & \\
\hline $\begin{array}{l}\text { Swartzioxylon naraense } \\
\text { Delteil-Desneux, } 1980 \\
\text { Tertiary/Tunisia }\end{array}$ & $\begin{array}{c}100 \mu \mathrm{m} \\
68-100 \mu \mathrm{m} \\
27 \text { vessels } \mathrm{mm}^{2}\end{array}$ & - & $\begin{array}{l}\text { vasicentric } \\
\text { confluent }\end{array}$ & $\begin{array}{c}\text { non } \\
\text { septate }\end{array}$ & $\begin{array}{c}12 \mathrm{~mm} \\
1-2 \text { seriate } \\
\text { homogeneous }\end{array}$ & + & $\begin{array}{l}\text { crystals in } \\
\text { chambered }\end{array}$ \\
\hline $\begin{array}{l}\text { Swartzioxylon naraense } \\
\text { Miocene/Brazil (this work) }\end{array}$ & $\begin{array}{c}85 \mu \mathrm{m} \\
31-137 \mu \mathrm{m} \\
22 \text { vessels } \mathrm{mm}^{2}\end{array}$ & $\begin{array}{c}\text { small } \\
\text { alternate } \\
\text { vestured }\end{array}$ & $\begin{array}{l}\text { vasicentric } \\
\text { aliform to } \\
\text { confluent }\end{array}$ & $\begin{array}{c}\text { non } \\
\text { septate }\end{array}$ & $\begin{array}{c}12 \mathrm{~mm} \\
1-2 \text { seriate } \\
\text { homogeneous }\end{array}$ & + & $\begin{array}{l}\text { crystals in } \\
\text { chambered }\end{array}$ \\
\hline
\end{tabular}


that of the extant genera in the Ingeae and Swartizieae tribes. Zygiaxylon gen. nov. and Swartzioxylon may have been important components of the flora during the Miocene in this region of the Amazon, and thus the presence of these genera contributes to our existing knowledge of the South America paleofloras. The fact that in the Miocene the temperature in the Brazilian Amazon was warmer and more humid may explain an increasing diversity in the flora.

The anatomy of these fossil woods shows characteristics similar to those of fossil specimens found in the Americas, Africa, and India. However, our current knowledge is still very fragmented and not yet sufficient to clearly show the biogeographic patterns and processes involved in the origin and differentiation of the Amazon flora. The taxa discussed in this work probably inhabited the upland forests and floodplains in Amazonia during the Miocene. AdamiRodrigues et al. (2013) support the interpretation of a fluvial environment with periodic flooding, reinforcing the theory that the Fabaceae can inhabit a diversity of environments.

\section{ACKNOWLEDGEMENTS}

The results discussed here were part of the Doctoral research of A.C. Kloster at the Universidad Nacional de Cordoba, Argentina, supported by a CONICET Beca Latinoamericana Tipo II. The authors are also grateful for support received under project number 01200.001631/2010-32 from MCTI Brazil, coordinated by K.A. Rodrigues. The authors are also thankful to P. Détienne for helpful bibliography, F.R. Negri and Universidade Federal do Acre for the samples collection and to the reviewers for their suggestions.

\section{REFERENCES}

Adami-Rodrigues, K.; Haag, N.A.; Kloster, C.A. \& Silveira, R.R. 2013. Dados geológicos e paleontológicos, Neógeno e Quaternário da Bacia do Acre, Vale do Juruá. In: REUNIÃO BRASILEIRA DE CLASSIFICAÇÃO DE SOLOS, 9, 2013. Guia de campo, Acre, Embrapa, p. 37-58.

APG III. 2009. An update of the Angiosperm Phylogeny Group classification for the orders and families of flowering plants: APG III. Botanical Journal of the Linnean Society, 161:105-121. doi:10.1111/j.1095-8339.2009.00996.x

Axelrod, D.I. 1992. Climatic pulses, a major factor in legume evolution. In: P.S. Herendeen \& D.L. Dilcher (eds.) Advances in legume systematics. 4. The Fossil Record, The Royal Botanic Gardens, p. 259-279.

Boureau, E. \& Salard, M. 1962. Sur un bois fossile du département de Bolivar (Colombie). Boletin de Geología Bucaramanga, 11:35-44.

Brea, M.; Aceñolaza, P.G. \& Zucol, A.F. 2001. Estudio paleoxilológico en la Formación Paraná, Entre Ríos, Argentina. Buenos Aires, Asociación Paleontológica Argentina, p. 7-17 (Publicación Especial 8).

Carlquist, S. 2001. Comparative wood anatomy, systematic, ecological, and evolutionary aspects of dicotyledon wood. Berlin, Springer-Verlag, 448 p. doi:10.1007/978-3-662-04578-7

Chattaway, M. 1932. Proposed standards for numerical values used in describing woods. Tropical Woods, 29:20-28.
Cozzo, D. 1951. Anatomía del leño secundario de las leguminosas Mimosoideas y Cesalpinoideas Argentinas silvestres y cultivadas. Instituto Nacional de Investigaciones de las Ciencias Naturales, 2:63-146.

Cunha, P.R.C. 2007. Bacia do Acre. Boletim de Geociências da Petrobras, 15:207-215.

Delteil-Desneux, F. 1980. Sur 1' association de trois bois fossiles dans un meme gisement tertiaire du Djebel Nara (Tunisie centrale). Review of Palaeobotany and Palynology, 31:289-310. doi:10.1016/0034-6667(80)90032-9

Détienne, P. \& Jacquet, P. 1983. Atlas of the woods of the Amazon and of adjoining regions (Atlas des bois de l'Amazanie et des regions voisines). Nogent-sur-Marne, Centre Technique Forestier Tropical, $640 \mathrm{p}$.

Ducke, A. 1925. Plantes nouvelles ou peu connues de la région amazonienne. III. Arquivos do Jardim Botânico do Rio de Janeiro, 4:12-28.

Ducke, A. 1930. Plantes nouvelles ou peu connues de la région amzonienne IV. Arquivos do Jardim Botânico do Rio de Janeiro, 5:101-189.

Ducke, A. 1943. New or noteworthy Leguminosae of the Brazilian Amazon. Boletim Técnico do Instituto Agronômico do Norte, 1:24.

Evans, J.A.; Gasson, P.E. \& Lewis, G.P. 2006. Wood anatomy of the Mimosoideae (Leguminosae). IAWA Journal, 5:1-117.

Franco M.J. \& Brea, M. 2010. Microlobiusxylon paranaensis gen. et sp. nov. (Fabaceae, Mimosoideae) from the PliocenePleistocene of Ituzaingó Formation, Paraná Basin, Argentina. Revista Brasileira de Paleontologia, 13:103-114. doi:10.4072/ rbp.2010.2.03.

Franco, M. J. 2011. Estudios Paleobotánicos de la Formación Ituzaingó (Pliceno-Pleistoceno), Cuenca del Río Paraná, Argentina. Universidad Nacional de Cordoba, Tesis de Doctorado, $368 \mathrm{p}$.

Gregory, M.; Poole, I. \& Wheeler, E. A. 2009. Fossil dicot wood names - annotated list with full bibliography. IAWA Journal, 6:1-220.

Gros, J.P. 1981. Nouveaux bois du Cénozoique d'Autriche et d'Ethiopie. Université Claude Bernard Lyon, Thèse 3 eme Cycle, 143 p.

Gros J.P. 1992. A synopsis of the fossil record of Mimosoid legume wood. In: P. Herendeen \& D.L. Dilcher (eds.) Advances in legume systematics. 4. The fossil record, The Royal Botanic Gardens, p. 69-83.

Herendeen, P.S.; Crepet, W.L. \& Dilcher, D.L. 1992. The fossil history of the Leguminosae: phylogenetic and biogeographic implications. In: P.S. Herendeen \& D.L. Dilcher (eds) Advances in Legume systematics. 4. The Fossil Record, The Royal Botanic Gardens, p. 303-316.

Hoorn, C. \& Wesselingh, F.P. 2010. Amazonia landscape and species evolution: a look into the past. Oxford, Wiley-Blackwell, 447 p.

Hoorn, C. 1993. Miocene incursions and the influence of Andean tectonics on the Miocene depositional history of northwestern Amazonia. Results of a palynostratigraphic study. Palaeogeography, Palaeoclimatology, Palaeoecology, 105:267309. doi:10.1016/0031-0182(93)90087-Y

Hoorn, C. 1994. Fluvial palaeoenvironments in the intracratonic Amazonas Basin (Early Miocene to early Middle Miocene, Colombia). Palaeogeography, Palaeoclimatology, Palaeoecology, 109:1-54. doi:10.1016/0031-0182(94)90117-1

Hoorn, C.; Guerrero, J.; Sarmiento, G.A. \& Lorente, M.A. 1995. Andean tectonics as a cause for changing drainage patterns in Miocene northern South America. Geology, 23:237-240. doi:10.1130/0091-7613(1995)023<0237:ATAACF>2.3.CO;2 
IAWA Committee. 1989. IAWA list of microscopic features for hardwood identification. IAWA Bulletin, 10:219-332.

InsideWood. 2004-onwards. Available at http:insidewood.lib.ncsu. edu/search; accessed on 22/08/2013.

Jacobs, B.F. 2004. Palaeobotanical studies from tropical Africa: relevance to the evolution of forest, woodland and savannah biomes. Philosophical Transactions of the Royal Society B, 359:1573-1583. doi:10.1098/rstb.2004.1533

Jaramillo, J.A.C.; Hoorn, C.; Silva, A.F.S.; Leite, F.P.; Herrera, F.; Quiroz, L.; Dino, R. \& Antonioli, L. 2010. The origin of the modern Amazon rainforest - implications of the palynological and paleobotanical record. In: C. Hoorn \& F.P. Wesseling (eds.) Amazonia, landscape and evolution: a look into the past, Blackwell Publishing, p. 317-334.

Kloster, A.; Gnaedinger, S.; Adami-Rodrigues, K. \& Urban, C. 2013. Novo registro de Zollernioxylon tinocoi Mussa (Leguminosae) no Vale do Juruá, Mioceno da Formação Solimões, Bacia do Acre, Brasil. Gaea, 8:26-32. doi: 10.4013/gaea.2012.81.04

Kribs, D.A. 1935. Salient lines of structural specialization in the wood rays of dicotyledons. Botanical Gazette, 96:547-557.

Lakhanpal, R.N. \& Prakash, U. 1970. Cenozoic plants from Congo. 1- Fossil woods from de Miocene of Lake Albert. Royal Museum of Central Africa, Geological Sciences, 64:1-20.

Latrubesse, E.M.; Cozzuol, M.; Silva-Caminha, S.A.F.; Rigsby, C.A.; Absy, M.L. \& Jaramillo, C. 2010. The Late Miocene paleogeography of the Amazon Basin and the evolution of the Amazon River system. Earth-Science Reviews, 99:99-124. doi:10.1016/j.earscirev.2010.02.005

León, W.J.H. 2008. Anatomía de madera em 31 especies de la subfamilia Mimosoideae (Leguminosae) en Venezuela. Revista Colombia Forestal, 11:113-135. doi:10.14483/udistrital.jour. colomb.for.2008.1.a08

Lutz, A.I. 1979. Maderas de Angiospermas (Anacardiaceae y Leguminosae) del Plioceno de la Provincia de Entre Ríos, Argentina. Facena, 3:39-63.

Machado, L.G.; Scheel-Ybert, R.; Bolzon, R.T.; Carvalho, M.A. \& Carvalho, I.S. 2012. Lenhos fósseis do Neógeno da Bacia do Acre, Formação Solimões. Contexto paleoambiental. Revista Brasileira de Geociências, 42:67-80.

Maia, R.G.; Godoy, H.K.; Yamaguti, H.S.; De Moura, P.A.; Da Costa, F.S.; De Holanda, M.A. \& Costa, J. 1977. Projeto de Carvão no Alto Solimões. Rio de Janeiro, CPRM-DNPM, 137 p.

Martínez, L.C.A. 2014. Fossil legume woods from the Late Miocene, Chiquimil Formation (Santa María Basin), Argentina. Review of Palaeobotany and Palynology, 201:1-11. doi:10.1016/j. revpalbo.2013.10.001

Metcalfe, C.R. \& Chalk, L. 1950. Anatomy of the Dicotyledons. Oxford, Clarendon Press, 731 p.

Miller, R.B. \& Détienne, P. 2001. Major timber trees of Guyana. Wood anatomy. Netherlands, Tropenbos International Wageningen, $218 \mathrm{p}$.

Müller-Stoll, W.R. \& Mädel, E. 1967. Die fossilen LeguminosenHölzer. Eine Revision der mit Leguminosen verglichenen fossilen Hölzer und Beschreibungen älterer und neuer Arten. Palaeontographica Abt B, 119:95-174.
Mussa, D. 1959. Contribuição a Paleoanatomia Vegetal II. Madeiras fósseis do território do Acre, Alto Juruá, Brasil. Rio de Janeiro, Instituto Brasileiro de Geografia e Estatística, 78 p. (Boletim 195).

Nikitin, A.A. 1935. A new wood from the Upper Pliocene of eastern Georgia. Trudy Neftyanogo Geologo Azvedochnogo Instituta, 51:51-52.

Pennington, T.D. 1997. The Genus Inga. Botany. Kew, Royal Botanical Gardens, 844 p.

Pons, D. \& De Franceschi, D. 2007. Neogene woods from western Peruvian Amazon and paleoenviromental interpretation. Bulletin of Geosciences, 82:343-354. doi:10.3140/bull. geosci.2007.04.343

Pons, D. 1980. Les bois fossile du Tertiaire Superieur de la region de Toluviejo-Corozal (Departamento de Sucre, Colombie). In: CONGRES NATIONAL DES SOCIETES SAVANTES, 105, 1980. Comptes Rendus, Caen, p. 163-182.

Prakash, U. 1975. Fossil woods from the Lower Siwalik beds of Himachal Pradesh, India. The Palaeobotanist, 22:192-210.

Prakash, U. \& Tripathi, P.P. 1968. Fossil woods of Adenanthera and Swintonia from the Tertiary of Assam. Current Science, 37:115-116.

Pujana, R.R.; Martinez, L.C.A. \& Brea, M. 2011. El registro de maderas fósiles de Leguminosae de Sudamérica. Revista Museu Argentino de Ciencias Naturales, 13:183-194.

Ramanujam, C.G.K. 1960. Silicified woods from the Tertiary rocks of South India. Palaeontographica Abt.B, 106:99-140.

Ribeiro, J.E.L. et al. 1999. Flora da Reserva Ducke: guia de identificação das plantas vasculares de uma floresta de terrafirme na Amazônia Central. Manaus, INPA/DFID, 816 p.

Schenk, A. 1883. Fossile Hölzer in K. Zittel -Beiträge zur Geologie und Paläontologie der Libyschen Wüste. II. Palaeontographica Abt.B, 30:1-19.

Selmeier, A. 2004. First record of Matisia (Bombacaceae) and Crudia (Caesalpiniaceae) wood from the Tertiary of Rio Paranaiba, Brazil. Zitteliana, 44:113-124.

Simpson, G.G. \& Paula-Couto. C. 1981. Fossil Mammal from the Cenozoic of Acre, Brazil III - Pleistocene Edentata Pilosa, Proboscidea, Sirenia, Perissodactyla and Artiodactyla. Iheringia, Série Geologia, 6:11-73.

Suguio, K. \& Mussa, D. 1978. Madeiras fosseis dos aluviões antigos do Rio Tiete, São Paulo. Boletim do IG-USP, 9:25-45. doi:0100-3879

Wanderley-Filho, J.R.; Eiras, J.F. \& Cunha, P.R.C. 2010. The Paleozoic Solimões and Amazonas basins and the Acre foreland basin of Brazil. In: C. Hoorn \& F.P. Wesseling (eds.) Amazonia, landscape and evolution: a look into the past, Blackwell Publishing, p. 29-37.

Wheeler, E. \& Baas, P. 1992. Fossil wood of the leguminosae: a case study in xylem evolution and ecological anatomy. In: P.S. Herendeen \& D.L. Dilcher (eds) Advances in Legume Systematics. 4. The Fossil Record, The Royal Botanic Gardens, p. 207-223.

Received in December, 2014; accepted in November, 2015. 